JOURNAL OF SECURITY AND SUSTAINABILITY ISSUES

ISSN 2029-7017 print/ISSN 2029-7025 online

2020 June Volume 9 Number 4

https://doi.org/10.9770/jssi.2020.9.4(7)

Scopus

\title{
IMPACT OF INTELLECTUAL CAPITAL ON FIRM VALUE THROUGH CORPORATE REPUTATION AS A MEDIATING VARIABLE
}

\author{
Putu Nidia Midiantari ${ }^{1}$, Dian Agustia ${ }^{2 *}$ \\ ${ }^{1}$ Department of Accounting, Faculty of Economics and Business, Universitas Airlangga, Indonesia \\ E-mail: ${ }^{2 *}$ dian.agustia@feb.unair.ac.id (Corresponding author)
}

Received 18 October 2019; accepted 30 March 2020; published 30 June 2020

\begin{abstract}
This study aims to examine the effect of intellectual capital on firm value through corporate reputation as a mediating variable. Intellectual capital is proxied by human capital, structural capital, and customer capital. Using the resource-based theory and signaling theory, this paper analyzes how the corporate reputation will be mediating intellectual capital to firm value. This study used 340 observations of companies that received an excellent category on the Indonesian Corporate Image Award (IMAC) which was listed on the Indonesia Stock Exchange in 2013 to 2017 with Partial Least Square (PLS) test processed with warpPLS version 5.0 software. This study shows that the first human capital, structural capital, customer capital, and corporate reputation have a significant effect on firm value. Second, structural capital has a significant effect on corporate reputation. Third, corporate reputation variables are able to mediate the influence of intellectual capital proxied by human capital, structural capital, and customer capital on firm value. This study is the first empirical investigation on the contribution of Intellectual Capital in generating value for corporate reputation. Furthermore, the study contributes to the literature on the link between Intellectual Capital and firm value by examining a sample of firms no yet explored in prior research and this study also uses the cost-based approach.
\end{abstract}

Keywords: corporate reputation; firm value; human capital; structural capital

Reference to this paper should be made as follows: Midiantari, P.N., Agustia, D. 2020. Impact of intellectual capital on firm value through corporate reputation as a mediating variable. Journal of Security and Sustainability Issues, 9(4), 1203-1213.

https://doi.org/10.9770/jssi.2020.9.4(7)

JEL Classifications: M41, G32, L14.

\section{Background}

In business competition at this time, the management of intellectual capital has an important role in the objectives of production activities. The purpose of production activities in business competition has begun to shift, previously the main production activities were only focused on the creation of finished goods, but at present the main focus of production activities in the process of creating finished goods in line with knowledge, and then the creation of goods and services (Pulic, 2000; Petrenko et al., 2019).

Guthrine et al. (2000) state that changes in ways of thinking in developing intellectual-based innovations can trigger the emergence of intellectual-based companies. The change in a labor-based business strategy to a knowledge-based business strategy that can later create value in new business processes (Sawarjuwono and Kadir, 2003; Mingaleva et al., 2019). Accordance with Barney (1991) in a knowledge based business which states that if the knowledge held by the company is managed properly, it can be used as a means to increase income which later affects the value of the company.

In Indonesia, businesses are required to be sensitive to intangible capital owned by the company. This is be- 
cause intangible capital is a supporting factor to win the competition in business and an inseparable part as a driver of the existence of intellectual property rights (IPR) in business competition. However, businessmen in Indonesia are not yet considerate to use of intellectual property rights (IPR). In the 2017 WIPR entitled Intangible Capital in Global Value Chains, it was found that the real value generated from asset intangibles reached US \$ 5.9 trillion in 2014 (an increase of $75 \%$ compared to income in 2000).

Edvinsson et al. (1996); Chen (2005); Tan et al. (2010); Haleblian et al. (2017); and Ginesti et al. (2018) assert that intellectual capital, which is proxied by value added intellectual coefficient (VAIC ${ }^{\mathrm{TM}}$ ), value added capital employed (VACA), value added human capital (VAHU), and structural capital value added (STVA) have a positively significant related effect with financial performance, and indicate that companies that maintain the reputation of companies tend to use intellectual capital efficiently and use it as a tool to predict company value.

This study aims specifically to determine whether corporate reputation variables can mediate the effect of intellectual capital on firm value. The analysis in this study used 340 companies with excellent categories on the Indonesian Corporate Image Award (IMAC) and listed on the Indonesia Stock Exchange for the period 20132017. The analysis model uses Partial Least Square (PLS) with the WarpPLS 5.0 instruments.

The results of this study prove that the first, human capital, structural capital, customer capital, and corporate reputation have a significant effect on firm value. Second, human capital and customer capital have no significant effect on corporate reputation, but structural capital has a significant effect on corporate reputation. Third, corporate reputation is able to mediate part of the effect of intellectual capital that is proxied by human capital, structural capital, and customer capital on firm value.

Furthermore, this study are able to contribute to proving the important key to intellectual capital for companies, in line with resources-based theory and signaling theory and the use of cost-based approaches where appropriate management of resources with expenditures to improve the competence of company employees and conveying information stakeholders can be used as a means to improve the company's reputation so that investors are more interested and will ultimately increase the value of the company. The use of the cost-based approach in this research is a new thing.

\section{Literature Review and Hypothesis}

Intellectual capital is closely related to resource-based theory. Wernerfelt (1984) explains that resource-based theory is that a company will gain a competitive advantage if it is able to manage its assets, either tangible assets or intangible assets. Penrose (1959) in Peteraf (1993) which states that companies can create economic value not only because they have the resources they need, but are able to effectively manage their resources. Another theory related to this research is signaling theory. Corporate reputation and company value variables relate to signaling theory because an action taken by company management can be a guide for stakeholders regarding how management views the company's prospects (Besley and Brigham, 2008). This signal is in the form of information about what has been done by management to realize the wishes of the owner.

\subsection{Effect of Human Capital on Firm Value}

Penrose (1956) and Peteraf (1993) asserts that companies can create economic value not only because they have the resources they need, but are able to manage their resources effectively. Human capital is the manager of the resources owned by the company and makes it a critical sector in creating competitive advantage (Barney, 1991). Nimtrakoon (2015); Ozkan et al., (2016); and Ginesti et al. (2018) states that human capital has a significant effect on firm value. Based on the statement described above, the first hypothesis of this study is:

H1: Human capital affects on Firm Value 


\subsection{Effect of Structural Capital on Firm Value}

Structural capital is the company's ability to produce organizational performance optimally (Sawarjuwono and Kadir, 2003). Structural capital includes all capital owned by companies other than humans, which includes databases, organizational structures, strategies, and anything that is of value to the company (Kalkan et al., 2014). The optimal company performance will increase the value of the company. Research by Li and Zhao (2017); Osiyevskyy (2017); Kalkan et al., (2014); and Forte et al., (2016) state that structural capital has a significant effect on firm value. Based on the statement described above, the second hypothesis of this study is:

\section{H2: Structural Capital affects on Firm Value}

\subsection{Effect of Customer Capital on Firm Value}

Companies are able to provide signals in the form of information relating to things that have been done by management to realize the wishes of the owner, so that the company is able to overcome asymmetric information using elements of intellectual capital, namely customer capital as a bridge with external parties. If the actual value of the company can be conveyed to the external party of the company, the market view of the company will rise, which results in the company's market value can increase (Penrose, 1956 in Peteraf, 1993; Barney, 1991). Berzkalne (2014); Osiyevskyy (2017); and Li and Zhao (2017) which state that customer capital has a significant effect and is positively related to firm value. Based on the statement described above, the third hypothesis of this study is:

\section{H3: Customer Capital affects on Firm Value}

\subsection{Effect of Human Capital on Corporate Reputation}

Based on resources-based theory which states that companies will gain a competitive advantage if they are able to manage their assets both tangible assets and intangible assets (Wernerfelt, 1984). Appropriate use of human resources can be related to company performance (Abeysekera, 2018), so that employees are considered as a vital component to be able to improve the company's reputation. Ginesti et al. (2018) which states that good corporate values will always maintain their reputation and tend to use elements of intellectual capital namely human capital efficiently. Based on the statement described above, the fourth hypothesis of this study is:

\section{H4: Human capital affects on Firm Value}

\subsection{Effect of Structural Capital on Corporate Reputation}

Structural capital is the company's ability to fulfill the company's routine process and its structure that supports employee performance. Companies that have a high commitment to the routine process and company structure to support employee performance will be appreciated by the community, so that it will enhance the company's reputation. Research by Kalkan et al., (2014); Forte et al., (2016); and Ginesti et al. (2018) states that structural capital that is used efficiently is closely related to company value and shows that the company can maintain the reputation of its company. Based on the statement described above, the fifth hypothesis of this study is:

H5: Structural capital affects on corporate reputation

\subsection{Effect of Customer Capital on Corporate Reputation}

If the signal given by the company has been able to realize the wishes of the owner, then the real value of the company can be conveyed to the external parties of the company, so that it can trigger an increase in reputation for the company (Ginesti et al., 2018). Research by Raithel et al. (2015); Mandariaga and Rivera (2017); and Ginesti et al. (2018) which states that customer capital has a significant and positively related effect on firm value and shows that companies that maintain the reputation of their companies tend to use intellectual capital assets efficiently. Based on the statement described above, the sixth hypothesis of this study is: 


\section{H6: Customer capital affects on corporate reputation}

\subsection{Effect of Corporate Reputation on Firm Value}

Osiyevskyy (2017) which states that management that can achieve company prospects well is a signal that the company has a good-future, so that it can convince investors or potential investors towards the company. Weng (2016) and Saeidi et al., (2015) stated that companies that have a good reputation provide a positive signal to investors. Based on the statement described above, the seventh hypothesis of this study is:

\section{H7: Corporate reputation affects on Firm Value}

\subsection{The Effect of Human Capital on Firm Values with Corporate Reputation as a mediating variable}

Resources-based theory explains that a company can create a competitive advantage that is superior to its competitors, if the company is able to manage its owned resources effectively (Wernerfelt, 1984). Ozkan et al., (2016) and Ginesti et al. (2018) states that the use of intellectual capital elements, namely human capital efficiently can reflect good corporate value and always maintain the reputation of the company. Based on the statement described above, the eighth hypothesis of this study is:

H8: Corporate reputation mediates the effect of human capital on firm value

\subsection{The Effect of Structural Capital on Firm Values with Corporate Reputation as a mediating variable}

Efficient utilization of resources of the company so as to be able to create competitive advantages from competitors, therefore the company's performance is considered to be optimal and able to improve the company's reputation while increasing the value of the company. Research by Kalkan et al., (2014); Forte et al., (2016); Li and Zhao (2017); Ginesti et al., (2018) explained that structural capital has a significant positive effect on firm value and shows that companies can maintain their reputation. Based on the statement described above, the ninth hypothesis of this study is:

H9: Corporate reputation mediates the effect of structural capital on firm value

\subsection{The Effect of Customer Capital on Firm Value with Corporate Reputation as a mediating variable}

Osiyevskyy (2017); Mandariaga and Rivera (2017); and Ginesti et al. (2018) states that customer capital has a significant effect on company value because the satisfaction obtained by the customer can improve the company's reputation, so that when the reputation of the company increases, the value of the company will also increase simultaneously. This is in line with signaling theory where the signal given by the company is related to the accountability of management activities to the owner of the company, so that good relations between stakeholders can be maintained. Based on the statement described above, the tenth hypothesis of this study is:

H10: Corporate reputation mediates the effect of customer capital on Firm Value

\section{Researh Method}

This study uses quantitative data sourced from the company's annual report that received an excellent category for the Indonesian Corporate Image Award (IMAC) and was listed on the Indonesia Stock Exchange (IDX) for the period 2013-2017. The total sample of the study was 340 companies that were selected using the purposive sampling method. 


\subsection{Dependent Variable}

The dependent variable used in this study is firm value which is proxied using Tobin's Q through the equation:

$$
\text { Tobin's Q }=\frac{\text { Market Value }+ \text { Liabilities }}{\text { Book Value }+ \text { Liabilities }}
$$

\subsection{Independent Variable}

The independent variable used in this study is intellectual capital, which is proxied into three as follows human capital (VAHU), structural capital (STVA), and customer capital (VACA) obtained through equations.

$$
\begin{aligned}
& \mathrm{VA}=\mathrm{OUT}-\mathrm{IN} \\
& \mathrm{VAHU}=\frac{\mathrm{VA}}{\mathrm{HC}} \\
& \mathrm{STVA}=\frac{\mathrm{ST}}{\mathrm{VA}} \\
& \mathrm{VACA}=\frac{\mathrm{VA}}{\mathrm{CE}}
\end{aligned}
$$

\subsection{Mediating Variable}

The mediation variable used in this study is corporate reputation. The measurement of mediating variables uses the dummy method, namely giving a score of 1 to companies that get excellent categories in a row during 2013-2017 and a score of 0 for companies that get the excellent category not consecutive during 2013-2017.

\subsection{Control Variable}

The control variables used in this study are the concentration of share ownership, company size, and leverage.

\subsection{Method}

The sample in this study was selected using a purposive sampling method. The data analysis technique used in this study is the measurement of outer model, inner model, and direct hypothesis testing (indirect effect) and indirect hypothesis testing (indirect effect).

\section{Result and Discussion}

The object of research examined in this study is the value of the company. The research population is companies that get an excellent category on the Indonesian Corporate Image Award (IMAC) for the 2013-2017 periods. The sample of this study was determined using a purposive sampling method with the final results of 340 companies.

Table 1. Descriptive Statistic.

\begin{tabular}{ccccc}
\hline & Mean & Median & Minimum & Maximum \\
\hline OC & 0.926 & 1.000 & 0.000 & 1.000 \\
\hline FIRMSIZE & 30.079 & 30.259 & 26.161 & 34.656 \\
\hline LEV & 0.522 & 0.497 & 0.000 & 1.470 \\
\hline VAHU & 2.581 & 1.873 & -2.020 & 52.399 \\
\hline STVA & 0.421 & 0.475 & -3.385 & 3.768 \\
\hline VACA & 0.398 & 0.287 & -2.567 & 13.136 \\
\hline FV & 1.253 & 0.749 & 0.168 & 12.774 \\
\hline CR & 0.706 & 1.000 & 0.000 & 1.000 \\
\hline
\end{tabular}




\subsection{The Results of Hypothesis Testing}

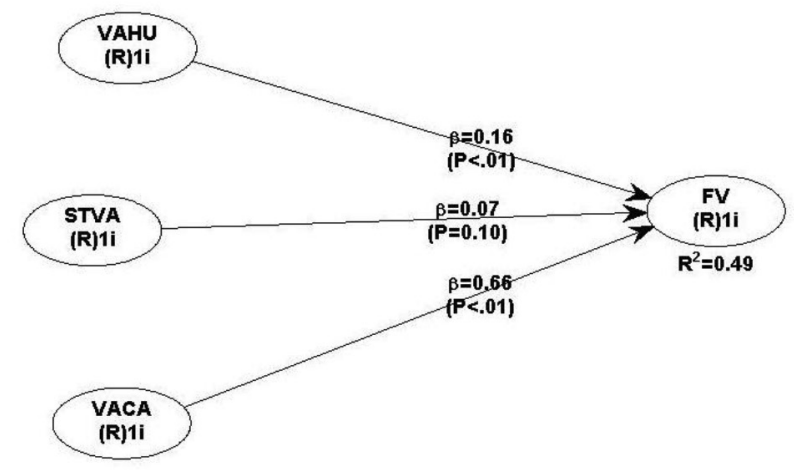

Figure 1. Direct Effect

Based on Figure 1 above, it can be concluded that there is a positive and significant direct relationship between intellectual capital, which is proxied by VAHU, STVA, and VACA before mediating variables are marked with the path coefficient, $0.16,0.07$ and 0,66 and the p-value is smaller than the 0.05 significance level of 0.01 .

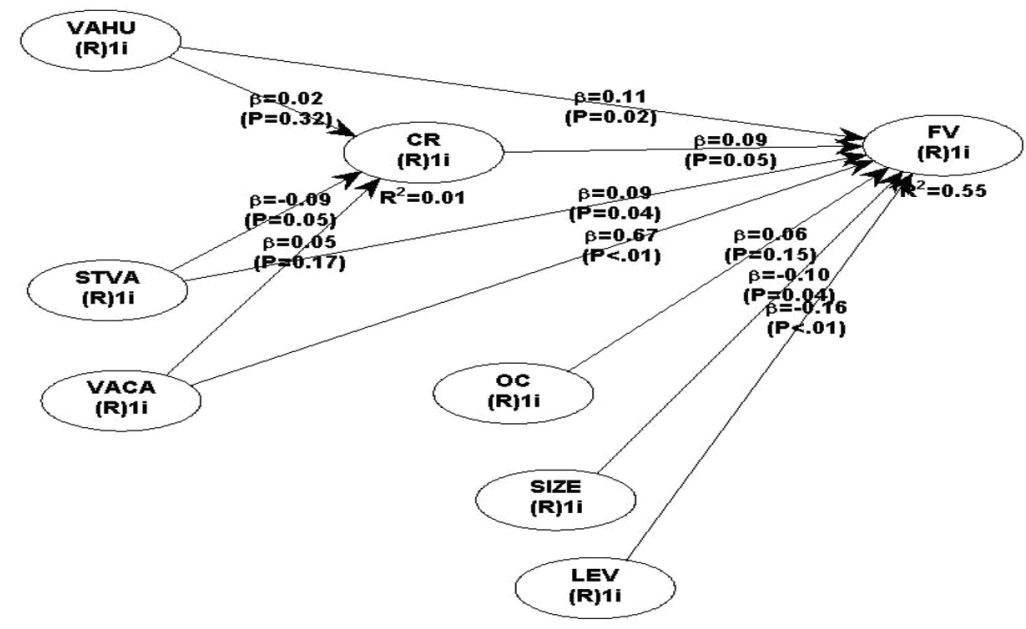

Figure 2. Indirect Effect

Figure 2 shows (1) the significant influence between VAHU and company value after adding mediation variables which can be seen through path coefficient 0.114 and p-value of 0.016 so that H1 is accepted, (2) Significant influence between STVA and firm value after the addition of mediating variables can be seen through the path coefficient of 0.094 and the p-value is less than the significance level of 0.05 which is equal to 0.04 so $\mathrm{H} 2$ is accepted, (3) Significant influence between VACA and firm value after adding mediating variables can be seen through path coefficient 0.673 and $p$ value -value is less than the significance level of 0.05 which is equal to $<0,001$ so that H3 is accepted, (4) Nonsignificant effect between VAHU and corporate reputation after adding mediating variables which can be seen through path coefficient 0.025 and p-value greater than significance level 0.05 which is 0.324 so that $\mathrm{H} 4$ is rejected, (5) Significant influence between STVA and corporate reputation ion after addition of mediation variables which can be seen through path coefficient -0.088 and p-value value is equal to the significance level of 0.05 which is 0.05 so that H5 is accepted, (6) Nonsignificant effect between VACA and corporate reputation after the addition of mediating variables can be seen through path coefficient 0.05 and p-value greater than the significance level of 0.05 which is 0.175 so that H6 is rejected, (7) Significant influence between corporate reputation and company value after adding mediating variables can be seen through path coefficient 0.091 and p-value value is less than the significance level of 0.05 which is equal to 0.045 so that $\mathrm{H} 7$ is accepted. 
Baron and Kenny (1986) state that if the path coefficient value between the independent variable and the dependent variable before and after the mediation variable has decreased the $p$-value that remains significant between the independent variables and the dependent variable can be stated that mediating variables are able to mediate partially, the effect of independent variables on the dependent variable. Comparison between the path coefficient between Figure 1 and Figure 2 shows that corporate reputation is able to mediate partially the influence of independent variables (human capital, structural capital, and customer capital) on the dependent variable (company value) so that it increases the value of the company. The eighth hypothesis, the ninth hypotheses, and the tenth hypothesis are declared acceptable.

\subsection{The Effect of Human Capital on Firm Value}

Resource-based theory has stated that companies can create economic value not only because they have the resources they need, but are able to manage resources that are owned effectively (Penrose, 1956 in Peteraf, 1993). One of the resources owned by the company is human capital. Berezinets et al. (2016) state that the main things in human capital are knowledge, skills, work experience, innovation, and creativity. In the end, these innovations will be able to support the value of the company as well. Ozkan et al. (2016); Nimtrakoon (2015); and Ginesti et al. (2018) states that human capital has a positive effect on financial performance and is found as a driver of value in the company, so that added value (value added) on human capital can increase the value of the company.

\subsection{The Effect of Structural Capital on Firm Value}

Resource-based theory which states that the resources owned by a company must be used efficiently and must be balanced with the existence of procedures and systems within the company. Ashton (2005) explains that structural capital is the ability possessed by a company to be able to manage the routine activities of a company with all the structures in it to support employee performance as a whole and can produce maximum corporate value. If the company does not use structurally owned capital, it can lead to the selection of a company strategy that is not appropriate so as to produce a negative impact on value in the company (Forte et al., 2016). The results of this study are in line with previous studies conducted by Li and Zhao (2017) and Osiyevskyy (2017) which state that structural capital has a significant positive effect on firm value.

\subsection{The Effect of Customer Capital on Firm Value}

Signaling theory states that a company must be able to establish good relations with external parties through a signal that is given to external parties in the form of financial statements. This is done to avoid the existence of asymmetric information between external parties so that indirectly the good relations that exist between companies and external parties can increase the value of the company. Companies that are able to maintain good relations with external parties are one example of the application of customer capital which is an element of intellectual capital. Berzkalne (2014); Osiyevskyy (2017); and Li and Zhao (2017) which state that customer capital has a significant positive effect on firm value.

\subsection{The Effect of Human Capital on Corporate Reputation}

According to the resource-based theory, companies will gain a competitive advantage if they are able to manage assets that are owned well (Wernerfelt, 1984). The increase in human capital in this study can cause an increase in corporate reputation but not significantly. This is because there are several factors that are most relevant in influencing the company's reputation directly including the selection of company strategies or establishing good relationships with external parties (Chen et al., 2005). Muhammad and Ismail (2009) and Li and Zhao (2017) stated that human capital does not have a significant effect on company performance and also the value of the company so that indirectly it does not affect the company's reputation. 


\subsection{The Effect of Structural Capital on Corporate Reputation}

In a resource-based theory, it has been stated that the resources owned by the company must be utilized efficiently and must be balanced with the existence of procedures for activities and systems that are appropriate in the company. Companies that are committed to procedures related to routines and good corporate structure to support employee performance will be appreciated by the outside community so that it can improve the company's reputation. Kalkan et al. (2014); Forte et al. (2016); and Ginesti et al., (2018) stated that companies that are committed to procedures related to routines and good corporate structures to support employee performance, will be appreciated by the outside community so as to enhance the company's reputation.

\subsection{The Effect of Customer Capital on Corporate Reputation}

Based on signaling theory which states that giving signals to external parties in the form of financial statements can establish good relations with stakeholders, these results indicate that interested external parties also give higher value to companies that pay attention to intangible assets other than customer capital owned by the company that is like the development of innovation from the company. Andreeva et al. (2016) stated that high customer capital is a common and unavailability of competitive advantages that are unique to the company. Nimtrakoon (2015); Andreeva et al. (2017); Ginesti et al. (2018) which states that customer capital has no significant effect on the company's reputation.

\subsection{The Effect of Corporate Reputation on Firm Value}

Signaling theory states that an action taken by the management of a company provides guidance to investors about how management views the company's prospects as one of which is creating a good corporate reputation (Besley and Brigham, 2001). Brammer \& Pavelin (2006); Walsh et al. (2006); Walsh, Mitchell, and Jackson (2009); Saeidi et al. (2015) and Weng (2016) which state that companies that have a good reputation provide a positive signal to investors, especially when the company is in trouble (distress) so that companies that have a good reputation can support the increasing value of the company.

\subsection{Corporate Reputation Mediates the Effect of Human Capital on Firm Value}

Based on the results of the study indicate that corporate reputation is able to mediate the influence of human capital on firm value. This is because the path coefficients before and after entering the corporate reputation result in a value that remains significant with the path coefficient experiencing a slight decrease. Human capital reflects the company's ability to produce the best solutions based on the values that are embedded in each individual company. In line with resources-based theory which states that utilizing assets owned by a company can provide a competitive advantage for the company (Wernerfelt, 1984). Cravens \& Oliver (2006) and Petkova et al. (2008) which states that human capital has a significant effect on corporate reputation because human capital plays an important role in the placement of the company's reputation.

\subsection{Corporate Reputation Mediates the Effect of Structural Capital on Firm Value}

Based on the results of testing, it shows that corporate reputation is able to mediate the influence of structural capital on firm value. The results of research conducted through statistical tests with the help of WarpPLS 5.0 software show that corporate reputation qualifies as a mediating variable, namely: path coefficient between the independent variable and the dependent variable is significant, the path coefficient between the independent variable and the mediating variable is significant, and the path coefficient between mediating variables and significant dependent variable. Resource-based theory which states that companies can utilize and manage assets owned by either tangible or intangible assets in order to create a competitive advantage for the company. This advantage will be an added value for the company to be able to compete in the global market chain. The results of this study are in line with Forte et al. (2016) which states that if a company can use structurally owned capital, then it will have an impact on the selection of the right corporate strategy so that it produces a good impact on the value of the company. 


\subsection{Corporate Reputation Mediates the Effect of Customer Capital on Firm Value}

Based on the results of the study indicate that corporate reputation is able to mediate the influence of customer capital on firm value. This is because corporate reputation variables fulfill the requirements as partially mediating variables. In addition, there is a stronger direct influence between the independent variables (customer capital) on the dependent variable (company value) in line with the indirect influence that is indicated by the presence of mediating variables, namely corporate reputation, resulting in test results that still have a significant effect. Customer capital reflects the company's ability to always optimize relationships with customers and other external parties in accordance with signaling theory. Osiyevskyy (2017) and Mandariaga and Rivera (2017) which states that customer capital has a significant effect on company value because the satisfaction obtained by the customer can improve the company's reputation, so that when the company's reputation increases, the value of the company will increase simultaneously.

\section{Conclusions}

For companies, with the aim of increasing company value, it takes effort and support from managers and employees to keep paying attention to the quality of work and maximize everything they master in their field, because it represents intellectual capital so that what is owned by the company is exploited to the company's progress. In addition, decision makers, especially investors, can use this independent variable as additional information to consider in terms of decision making and for subsequent researchers to be encouraged to add a number of variables such as company performance or the company's financial performance.

\section{References}

Abeysekera, I. (2017). How Best to Communication Intangible Resources on Website to Inform Corporate-Growth Reputation of Small Entrepreneurial Business. Journal of Small Business Management. Retrieved from https://doi:10.1111/fsbm.12320

Andreeva, T., \& Garanina, T. (2016). Do All Elements of Intellectual Capital Matter for Organizational Performance? Evidence from Russian Context. Journal of Intellectual Capital. Retrieved from https://doi.org/10.1108/JIC-07-2015-0062

Ashton, R. H. (2005). Intellectual capital and value creation: a review. Journal of accounting literature, $24,53$.

Barney, J. (1991). Firm Resources and Sustained Competitive Advantage. Journal of Management, 99-120.

Berezinets, I., Garanina, T., \& Ilina, Y. (2016). Intellectual Capital of A Board of Directors and Its Elements: Introduction To The Concepts. Journal of Intellectual Capital, 632-653. Retrieved from https://doi.org/10.1108/JIC-01-2016-0003

Berzkalne, I., \& Zelgalve, E. (2014). Intellectual Capital and Company Value. Social and Behavioral Sciences. Retrieved from https:// doi.org/10.1016/j.sbspro.2013.12.394

Besley, S., \& Brigham, E. F. (2008). Essentials of Managerial Finance. United State of Ameria: Thomson South-Western.

Brammer, S. J., \& Pavelin, S. (2006). Corporate reputation and social performance: The importance of fit. Journal of management studies, 43(3), 435-455. Retrieved from https://doi.org/10.1111/j.1467-6486.2006.00597.x

Chen, M. (2005). An Empirical Investigation of The Relationship Between Intellectual Capital and Firms' Market Value and Financial Performance. 159-176. Retrieved from https://doi.org/10.1108/14691930510592771

Cravens, K. S., \& Oliver, E. G. (2006). Employees: The key link to corporate reputation management. Business Horizons, 49(4), 293302. Retrieved from https://doi.org/10.1016/j.bushor.2005.10.006

Edvinsson, L., \& Sullivan, P. (1996). Developing a model for managing intellectual capital. European management journal, 14(4), 356364. Retrieved from https://doi.org/10.1016/0263-2373(96)00022-9

Forte. (2016). Measuring The Intellectual Capital of Italian Listed Companies. Journal of Intellectual Capital. Retrieved from https:// doi.org/10.1108/JIC-08-2016-0083

Ginesti, G., Caldarelli, A., \& Zampella, A. (2018). Exploring The Impact Of Intellectual Capital On Company Reputation And Performance. Journal of Intellectual Capital, 915-934. Retrieved from https://doi.org/10.1108/JIC-01-2018-0012

Guthrie, J., Ricceri, F., \& Dumay, J. (2012). Reflections and projections: a decade of intellectual capital accounting research. The British 
accounting review, 44(2), 68-82. Retrieved from https://doi.org/10.1016/j.bar.2012.03.004

Haleblian, J. J., Pfarrer, M. D., \& Kiley, J. T. (2017). High-Reputation Firms and Their Differential Acquisition Behaviors. Strategic Management Journal, 2237-2254. Retrieved from https://doi.org/10.1002/smj.2645

Kalkan, A., Bozkurt, O. C., \& Arman, M. (2014). The Impacts Of Intellectual Capital, Innovation, and Organizational Strategy On Firm Performance. Social and Behavioral Sciences, 700-707. Retrieved from https://doi.org/10.1016/j.sbspro.2014.09.025

Li, Y., \& Zhao, Z. (2018). The Dynamic Impact of Intellectual Capital On Firm Value: Evidence From China. Applied Economics Letters, 19-23. Retrieved from https://doi.org/10.1080/13504851.2017.1290769

Mandariaga, J. G., \& Rivera, F. R. (2017). Corporate Social Responsibility, Customer Satisfiction, Corporate Reputation, and Firms' Market Value: Evidence From The Automobile Industry. Spanish Journal of Marketing, 39-53.

Mingaleva, Zh., Deputatova L., Akatov N., Starkov, Y. Mitrofanova, E. (2019). Application of HADI-cycle for providing sustainability of processes of knowledge and innovation. Entrepreneurship and Sustainability Issues 7(2), 1628-1640. http://doi.org/10.9770/ jesi.2019.7.2(58)

Muhammad, N. M. N., \& Ismail, M. K. A. (2009). Intellectual capital efficiency and firm's performance: Study on Malaysian financial sectors. International journal of economics and finance, 1(2), 206-212.

Nimtrakoon, S. (2015). The Relationship Between Intellectual Capital, Firms’ Market Value And Financial Performance: Empirical Evidence From The ASEAN. Journal of Intellectual Capital, 587-618. Retrieved from https://doi.org/10.1108/JIC-09-2014-0104

Osiyevskyy, O., \& Amy, M. Q. (2017). Maximizing The Strategy Value Of Corporate Reputation: A Business Model Perspective. Strategy and Leadership, 24-32. Retrieved from https://doi.org/10.1108/SL-05-2017-0043

Ozkan, N., Cakan, S., \& Kayacan, M. (2016). Intellectual Capital and Financial Performance: A Study of The Turkish Banking Sector. Borsa Istanbul Review. Retrieved from https://doi.org/10.1016/j.bir.2016.03.001

Peteraf, M. A. (1993). The cornerstones of competitive advantage: a resource-based view. Strategic management journal, 14(3), 179191. Retrieved from https://doi.org/10.1002/smj.4250140303

Petkova, A. P., Rindova, V. P., \& Gupta, A. K. (2008). How can new ventures build reputation? An exploratory study. Corporate Reputation Review, 11(4), 320-334.

Petrenko, Y., Vechkinzova, E., Antonov, V. (2019). Transition from the industrial clusters to the smart specialization of the regions in Kazakhstan. Insights into Regional Development, 1(2), 118-128. https://doi.org/10.9770/ird.2019.1.2(3)

Pulic, A. (2000). VAICTM_an accounting tool for IC management. International journal of technology management, 20(5-8), 702-714. Retrieved from https://doi.org/10.1504/IJTM.2000.002891

Raithel, S., Wilczynzki, P., Matthias, P. S., \& Schwaiger, M. (2015). The Value-Relevance of Corporate Reputation During The Financial Crisis. Journal of Product and Brand Management, 389-400. Retrieved from https://10.1108/10610421011085703

Saeidi, S. P., Sofian, S., Saeidi, P., Saeidi, S. P., \& Saaeidi, S. A. (2015). How does corporate social responsibility contribute to firm financial performance? The mediating role of competitive advantage, reputation, and customer satisfaction. Journal of business research, 68(2), 341-350. Retrieved from https://doi.org/10.1016/j.jbusres.2014.06.024

Sawarjuwono, T., \& Kadir, A. P. (2003). Intellectual capital: Treatment, measurement and reporting (a research library). Journal of accounting and finance, 5 (1), 35-57. Retrieved from https://doi.org/10.9744/jak.5.1.pp.\%2035-57 (in Bahasa)

Tan, H. P., Plowman, D., \& Hancock, P. (2010). Intellectual Capital and Financial Returns of Companies. Retrieved from https://doi. org/10.1108/14691930710715079

Walsh, G., Dinnie, K., \& Wiedmann, K. P. (2006). How do corporate reputation and customer satisfaction impact customer defection? A study of private energy customers in Germany. Journal of Services Marketing. Retrieved from https://doi.org/10.1108/08876040610691301

Walsh, G., Mitchell, V. W., Jackson, P. R., \& Beatty, S. E. (2009). Examining the antecedents and consequences of corporate reputation: A customer perspective. British journal of management, 20(2), 187-203. Retrieved from https://doi.org/10.1111/j.1467-8551.2007.00557.x

Weng, P.-s., \& Chen, W. Y. (2016). Doing Good or Choosing Well? Corporate Reputation, CEO Reputation, and Corporate Financial Performance. North American Journal of Economic and Finance. Retrieved from https://dx.doi.org/10.1016/j.najef2016.10.008

Wernerfelt, B. (1984). A resource-based view of the firm. Strategic management journal, 5(2), 171-180. Retrieved from https://doi. 
org/10.1002/smj.4250050207

\section{Acknowledgements}

The authors would like to thank the editor and anonymous reviewers for their supportive comments and suggestions. The authors received no direct funding for this research.

Putu Nidia MIDIANTARI is a student of Universitas Airlangga, Indonesia. Her current research interest is in management accounting. ORCID ID: orcid.org/0000-0002-8255-5194

Dian AGUSTIA is a Professor of Accounting in Universitas Airlangga, Indonesia. Her current research interests are sustainability accounting and management accounting.

ORCID ID: orcid.org/0000-0003-4669-7344

This work is licensed under the Creative Commons Attribution International License (CC BY). http://creativecommons.org/licenses/by/4.0/ 